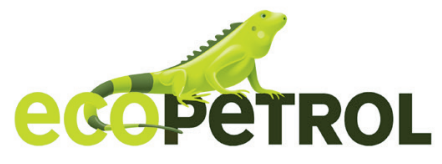

ctyf@ecopetrol.com.co
PROCESS OPTIMIZATION FOR BIODIESEL PRODUCTION FROM NEUTRALIZED WASTE COOKING OIL AND THE EFFECT OF THIS BIODIESEL ON ENGINE PERFORMANCE
OPTIMIZACIÓN DEL PROCESO DE PRODUCCIÓN DE BIODIESEL A PARTIR DE ACEITE DE COCINA USADO NEUTRALIZADO Y EVALUACIÓN DE SU DESEMPEÑO EN UN MOTOR

Eryilmaz, Tanzera*; Aksoy, Fatih ${ }^{b} ;$ Aksoy, Lacinec; Bayrakceken, Huseyin ${ }^{b} ;$ Aysal, Faruk-Emre ${ }^{b}$; Sahin, Seda ; Yesilyurt, Murat-Kadire

\section{ABSTRACT}

In this study, the methyl ester production process from neutralized waste cooking oils is optimized by using alkali-catalyzed $(\mathrm{KOH})$ single-phase reaction. The optimization process is performed depending on the parameters, such as catalyst concentration, methanol/oil ratio, reaction temperature and reaction time. The optimum methyl ester conversion efficiency was $90.1 \%$ at the optimum conditions of $0.7 \mathrm{wt} \%$ of potassium hydroxide, 25 wt $\%$ methanol/oil ratio, $90 \mathrm{~min}$ reaction time and $60^{\circ} \mathrm{C}$ reaction temperature. After the fuel characteristics of the methyl ester obtained under optimum conditions were determined, the effect on engine performance, $\mathrm{CO}$ and $\mathrm{NO}_{x}$ emissions of methyl ester was investigated in a diesel engine with a single cylinder and direct injection. When compared to diesel fuel, engine power and torque decreased when using methyl ester, and specific fuel consumption increased. NOx emission increases at a rate of $18.4 \%$ on average through use of methyl ester.

\section{RESUMEN}

Este estudio analiza el proceso de producción de metil éster a partir de aceites de cocina usados y neutralizados mediante una reacción alcalí-catalizada $(\mathrm{KOH})$ de fase única. El proceso de optimización se lleva a cabo tomando en cuenta parámetros tales como: La concentración del catalizador, la relación metanol/aceite, la temperatura de reacción y el tiempo de reacción. La eficiencia óptima de conversión del metil éster fue de 90,1\% bajo condiciones óptimas de 0,7 wt\% de hidróxido de potasio, 25 wt $\%$ de relación metanol/aceite, tiempo de reacción de 90 minutos y temperatura de reacción de $60^{\circ} \mathrm{C}$. Después de determinar las características como combustible del metil éster obtenido bajo condiciones óptimas, se sometió a investigación su efecto sobre el desempeño del motor y de las emisiones de $\mathrm{CO}$ y $\mathrm{NO}_{x}$ del metil éster utilizando un motor diesel de un sólo cilindro y de inyección directa. Cuando se compararon los resultados con el combustible diesel, se observó que la potencia y el torque del motor disminuyeron utilizando metil éster, mientras que el consumo de combustible específico aumentó. La emisión de NOx aumenta a una tasa de $18,4 \%$ en promedio cuando se utiliza el metil éster.
Neutralized Waste Cooking Oil | Methyl ester | Optimization I Engine Performance | Emission Aceite de Cocina Usado Neutralizado I Metil éster | Optimización | Desempeño del motor I Emisión a Department of Biosystems Engineering- Bozok University,66200, Yozgat, Turkey. ${ }^{b}$ Department of Automotive Engineering-Afyon Kocatepe University, Afyonkarahisar, Turkey.

${ }^{c}$ Department of Chemical- Afyon Kocatepe University, Afyonkarahisar, Turkey. ${ }^{d}$ Department of Agricultural Machinery - Selcuk University, Konya, Turkey. e Department of Mechanical Engineering- Bozok University, Yozgat, Turkey. *email: tanzer.eryilmaz@bozok.edu.tr 


\section{INTRODUCTION}

Compression ignition $(\mathrm{Cl})$ engines are widely used in transport, automotive, and industrial sectors as well as agricultural applications due to their higher fuel conversion efficiencies and greater ease of operation. Compression-ignition engines run with diesel fuel derived from petroleum. Oil resources are limited and rapidly diminishing. Crude oil production is also quite expensive and difficult. In addition, unburned hydrocarbons, carbon monoxide, nitrogen oxide, and smoke content in diesel fuel emissions are regulated by law in many countries. Today, many studies are conducted to reduce emissions with changes to engine operating parameters such as valve timing, injection timing, and atomization rate. At the same time, the reduction in reserves of fossil energy sources and their impact on the environment have led to a number of studies on alternative sources of energy [1]. Vegetable oils are one of these alternative energy sources [2]-[6].

Vegetable oils are obtained from renewable plants such as canola, rapeseed, soybean, flax, sunflower seeds, and corn. Vegetable oils are considered as a source of alternative energy due to their advantages in that they contain lower amounts of sulfur, oxygen is present in their structure, their cetane numbers are high and they produce less harmful emissions as a result of burning. In addition, a higher flash point and better lubricating properties are among the positive characteristics of vegetable oils. Vegetable oils have high viscosity and low volatility. High viscosity leads to the clogging of engine fuel systems and filters, increased injector opening pressure, poor atomization, and longer combustion duration in comparison to petroleum-based fuels. Therefore, vegetable oils are not directly used, and pre-treatment processes are applied to reduce the high viscosity. For this purpose, vegetable oils are used after blending with diesel fuel at certain proportions, heating, or producing biodiesel [7]-[10]

Biodiesel is the mono-alkyl esters of long-chain fatty acid derivatives in vegetable and animal oils. This event, which occurs as a result of the reaction of fatty acids with alcohols, is referred to as transesterification or alcoholysis. Transesterification is a chemical reaction used to lower the viscosity of oils. In these reactions, vegetable or animal oils react with a mono-alcohol such as methanol in the presence of a catalyst. Acidic or basic catalysts are used in the esterification reaction. If the free fatty acids (FFA) ratio in the oil is greater than $1 \%$, then an acid catalyst is preferred for the production of biodiesel. That is because the free fatty acids in the oil react with alkali catalysts and lead to the formation of soap. Soap makes the separation of glycerin from the reaction medium difficult. In addition, the formation of soap increases viscosity and decreases the efficiency of methyl ester. For these reasons, the oil should not contain more than 1\% FFA in alkali-catalyzed reactions. $\mathrm{NaOH}$ and $\mathrm{KOH}$ are widely used as the homogenous catalyst in transesterification reactions. For these catalysts to be used in the reaction, the FFA ratio in the oil should be less than 1\% [11]-[12].
There are a number of studies on optimizing the production of biodiesel and testing the biodiesel produced on engines. [13] determined the optimum conditions of biodiesel production from Karanja oil using alkali catalysts. They examined the effects of reaction parameters such as catalyst ratio, alcohol - oil ratio, reaction temperature, and mixing ratio on the production of Karanja oil methyl ester. They identified the efficiency of conversion of Karanja oil into methyl ester as 97-98\% under optimum conditions.

Phan [14] examined the effect of methanol-oil ratio, potassium hydroxide concentration, and the reaction temperature on the production of biodiesel from waste cooking oil. They achieved the optimum yield of $88-90 \%$ at 7:1-8:1 methanol/oil ratio, $30-50^{\circ} \mathrm{C}$ reaction temperature, and $0.75 \% \mathrm{KOH}$ catalyst concentration.

Aksoy [15] used an alkali catalyzed one-step reaction to produce poppy oil methyl ester. He optimized parameters such as catalyst ratio, methanol ratio, and reaction temperature. Optimum conditions were determined to be $20 \%$ methyl alcohol/oil ratio, $0.5 \%$ catalyst concentration and $60^{\circ} \mathrm{C}$ reaction temperature.

Kafuku [16] optimized the production of biodiesel from croton megalocarpus oil. They obtained the optimum biodiesel conversion efficiency as $88 \%$ under the optimization conditions of $1.0 \%$ catalyst concentration $(\mathrm{KOH}), 30 \%$ methyl alcohol/oil ratio, $60^{\circ} \mathrm{C}$ reaction temperature, $400 \mathrm{rpm}$ rotation speed, and 60 minutes reaction time.

Alptekin [17] optimized the production of chicken oil methyl ester. They used sodium hydroxide, potassium hydroxide, potassium methoxide, and sodium methoxide as catalysts. They used methanol as the alcohol in the transesterification reaction. They examined the effects of optimization parameters such as catalyst type, reaction temperature, and reaction time on the fuel characteristics.

Sahoo [18] optimized production conditions of biodiesel from jatropha, karanja, and polanga oils. They examined the effect of catalyst ratio, alcohol ratio, and reaction time on the biodiesel conversion efficiency.

Aksoy [19] Optimized the production of biodiesel with the transesterification method from safflower oil. The optimum biodiesel conversion efficiency of $93.4 \%$ was obtained at $0.5 \%$ catalyst concentration, 20\% methanol-oil ratio, 60 min reaction time, and $60^{\circ} \mathrm{C}$ reaction temperature.

In this study, using the transesterification method, methyl ester was produced from neutralized waste cooking oil at the maximum conversion efficiency depending on the reaction temperature, catalyst concentration, methyl alcohol/oil ratio, and the reaction time. The effect of methyl ester produced under maximum conditions on $\mathrm{CO}$ and $\mathrm{NO}_{x}$ emissions was investigated in a single cylinder, air-cooled, direct injection diesel engine.

\section{METHYL ESTER PRODUCTION AND OPTIMIZATION PROCESS}

Waste cooking oil was obtained from a commercial company. And it was used after neutralization. Waste vegetable oil was subjected to physical cleaning; waste particles that remained after frying were removed and the oil was moved into a settling tank in the manufacturing plant.
The waste vegetable oil in this tank was heated up to $100^{\circ} \mathrm{C}$, left to stand at this temperature for 2 hours under vacuum, and the water accumulated in the oil during the course of use was removed.

After the removal of water in the waste vegetable oil, the oil was transferred to the reactor tank and left until its temperature dropped to $85^{\circ} \mathrm{C}$. Keeping this temperature constant, the reactor stirrer was operated, phosphoric acid at a rate of $0.2 \%$ of the oil was added for 
the neutralization process, and the mix was stirred for 10 minutes. While mixture was being stirred, a mixture of sodium hydroxide/ distilled water at $1 / 3$ ratio was added to the waste vegetable oil at a ratio of $5 \%$ of the oil, and the mixture was stirred for another 5 minutes. The stirrer was turned off, the mixture was left to stand for 3 hours for the settling of phosphorus compounds, and the phosphorus compounds were subsequently removed. The waste vegetable oil was heated up to $85^{\circ} \mathrm{C}$ again and washed with water at a ratio of $20 \%$ of the oil at the same temperature, using the showering method. The mixture was left to stand for 3 hours for the waste water to settle and then the waste water was removed from the medium. For the removal of the waste water in the vegetable oil, the mixture was dried at $100^{\circ} \mathrm{C}$ for 2 hours under vacuum. Waste vegetable oil was left to stand until its temperature once again dropped to $85^{\circ} \mathrm{C}$; the reactor stirrer was operated; bleaching earth was added at a ratio of $2 \%$ of the oil, and the mixture was stirred for 45 minutes. Then the reactor stirrer was turned off and the mixture was left to stand for 3 hours for the bleaching earth to settle; afterwards, the settled bleaching earth was removed from the medium. Following the neutralization process, the waste vegetable oil was filtered using an oil plate filter [20]. Free fatty acid ratio of the waste vegetable oil was detected to be $0.65 \%$ by applying the titration method after the neutralization process.

99.5\% pure methyl alcohol (Merck, $\mathrm{d}=0.791-0.792 \mathrm{~kg} / \mathrm{l}$ ) and $\mathrm{KOH}$ as a catalyst (Merck) were used in the transesterification reaction. $50 \mathrm{~g}$ of oil was used in the experiments. The catalyst and methyl alcohol mixture was heated on the heater with a stirrer, under a reflux condenser at $40^{\circ} \mathrm{C}$ for 30 minutes. $50 \mathrm{~g}$ of neutralized waste cooking oil was added onto the catalyst-methyl alcohol mixture and this was heated under reflux. A rotational speed of $600 \mathrm{rpm}$ was used in the experiments. At the end of the reaction period, the mixture in the flask was taken to a separating funnel to separate the phases. After removing the glycerin phase that formed at the bottom of the separation funnel, the methyl ester was obtained. Methyl ester was washed with distilled water at $90^{\circ} \mathrm{C}$ to remove the residues. Then, the water in the methyl ester was removed by applying a drying process.

The reaction temperature, the methyl alcohol/oil ratio, the catalyst concentration, and the reaction time were used as the reaction parameters during the optimization process. The methyl alcohol ratio was changed at $5 \%$ intervals between $20 \%-40 \%$ of oil by weight. The catalyst concentration was determined to be $0.3 \%-1.1 \%$ of the oil by weight in $0.2 \%$ increments. The temperature was changed from $40^{\circ} \mathrm{C}$ to $80^{\circ} \mathrm{C}$ at $10^{\circ} \mathrm{C}$ intervals. The reaction time ranged between 30 min and 150 min at 30 min intervals. The methyl ester conversion efficiency is the ratio of the amount of methyl ester obtained to the amount of oil used.

\section{EXPERIMENTAL DEVELOPMENT}

The experiments were performed in a diesel engine with a single cylinder, four strokes, air cooling and direct injection. The technical specifications of the experimental engine are provided in Table 1.

Table 1. Technical specifications of the experimental engine

\begin{tabular}{|l|l|}
\hline \multicolumn{1}{|c|}{ Items } & Specifications \\
\hline Trademark & Antor 3 LD 510 \\
\hline Numbers of cylinders & 1 \\
\hline Volume $\left(\mathrm{cm}^{3}\right)$ & 510 \\
\hline Bore/stroke $(\mathrm{mm})$ & $85 / 90$ \\
\hline Compression ratio & $17.5 / 1$ \\
\hline Maximum engine Torque $(\mathrm{Nm} / \mathrm{rpm})$ & $32.8 / 1800$ \\
\hline Cooling system & Air cooled \\
\hline Maximum engine power $(\mathrm{kW} / \mathrm{rpm})$ & $9 / 3000$ \\
\hline
\end{tabular}

Before the experiment, the engine oil and filter were replaced. At the beginning of the experiment, the engine was operated and heated for nearly 10 minutes, and the measurements were performed after the engine reached operating temperature. The first test was conducted with diesel fuel. In terms of diesel fuel and biodiesel fuels, the engine moment, engine power, specific fuel consumption, $\mathrm{CO}$ and $\mathrm{NO}_{\mathrm{x}}$ emission values were measured. An electric dynamometer, which has a load cell at a sensitivity of 0.01, was used for measurements in relation to the engine moment. The experiments were performed under full load conditions between the engine revolutions of 1100 $3000 \mathrm{rpm}$. A Testo $350 \mathrm{XL}$ brand mobile gas analysis device was used to perform $\mathrm{NO}_{\mathrm{x}}$ and $\mathrm{CO}$ exhaust emission measurement. Schematic representation of the engine test assembly is shown in Figure 1. Information on the accuracies of the measurement equipment and uncertainties of the calculated results is provided in Table 2.

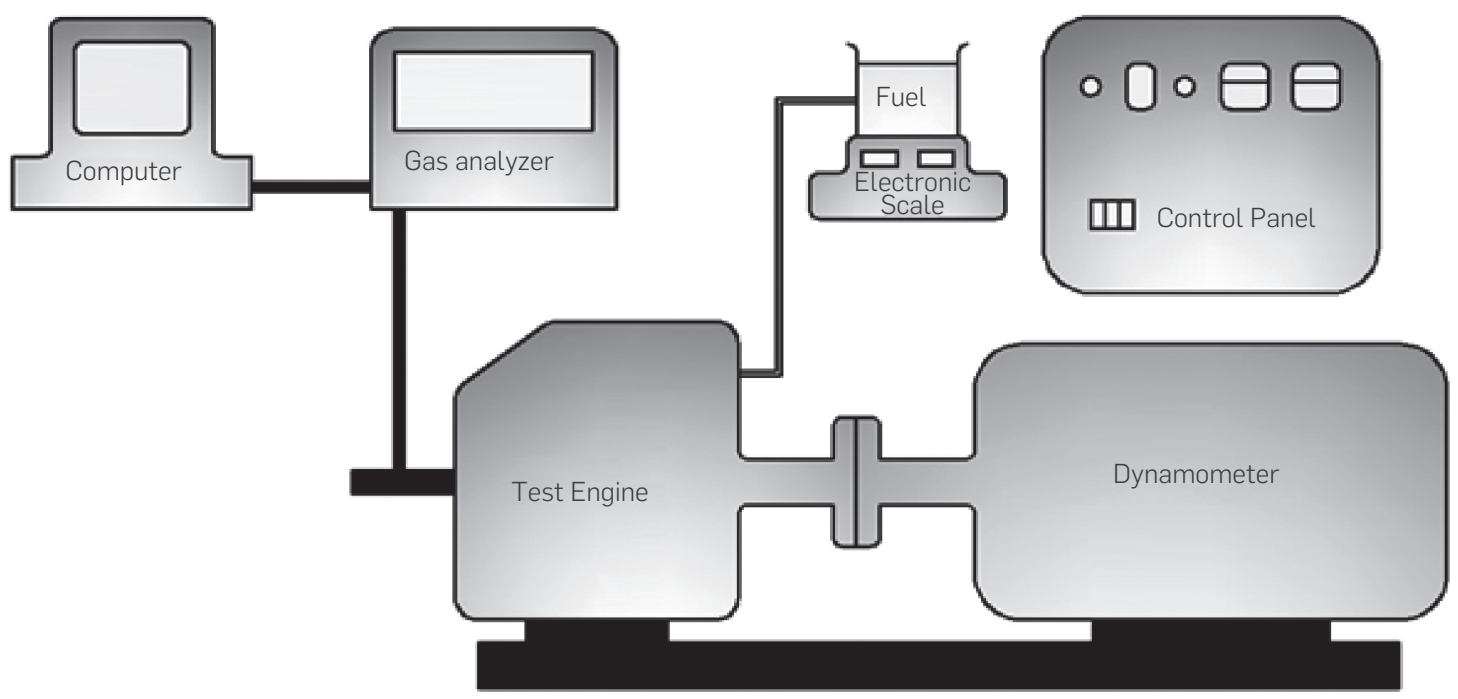

Figure 1. Schematic representation of the test system 
Table 2. Accuracies of the measurements and the uncertainties in the calculated results

\begin{tabular}{|l|l|}
\hline Items & Specifications \\
\hline Fuel $(\mathrm{g})$ & Accuracy $= \pm 1 \mathrm{~g}$ \\
\hline Time $(\mathrm{s})$ & Accuracy $= \pm \% 0.5$ \\
\hline Torque $(\mathrm{Nm})$ & Uncertainty $= \pm \% 1$ \\
\hline Power $(\mathrm{kW})$ & Uncertainty $= \pm \% 1.41$ \\
\hline SFC $(\mathrm{g} / \mathrm{kWh})$ & Uncertainty $= \pm \% 1.5$ \\
\hline CO $(\mathrm{ppm})$ & Accuracy $= \pm 1 \mathrm{ppm}$ \\
\hline NOx $(\mathrm{ppm})$ & Accuracy $= \pm 1 \mathrm{ppm}$ \\
\hline CO $(\mathrm{ppm})$ & Accuracy $= \pm 1 \mathrm{ppm}$ \\
\hline
\end{tabular}

\section{RESULTS AND ANALYSIS}

\section{METHYL ESTER OPTIMIZATION PROCESS}

Transesterification reactions are catalyzed with alkaline, acidic, or enzymatic catalysts. When there is water in the structure of the oil and the oil has high free fatty acid content, the acidic catalysts are preferred as the catalyst of the reaction. On the other hand, alkali catalysts are preferred in the transesterification process for oils with low free fatty acid content. $\mathrm{NaOH}$ and $\mathrm{KOH}$ are the most commonly used alkali catalysts [15].

The effect of catalyst concentration on the transformation of the methyl ester is provided in Figure 2. In this process, a 25\% methyl alcohol/oil ratio, $60^{\circ} \mathrm{C}$ reaction temperature, $600 \mathrm{rpm}$ stirring speed, and 90 -minute reaction time were kept constant. The maximum methyl ester conversion efficiency was obtained at $0.7 \%$ catalyst concentration. The methyl ester conversion efficiency decreased at catalyst concentrations lower and higher than this ratio. At low catalyst concentrations, the amount of catalyst is insufficient to complete the reaction. At high catalyst concentrations, the alkali catalyst reacts with free fatty acids in the oil to form soap and causes a decrease in the efficiency of methyl ester [13]-[15].

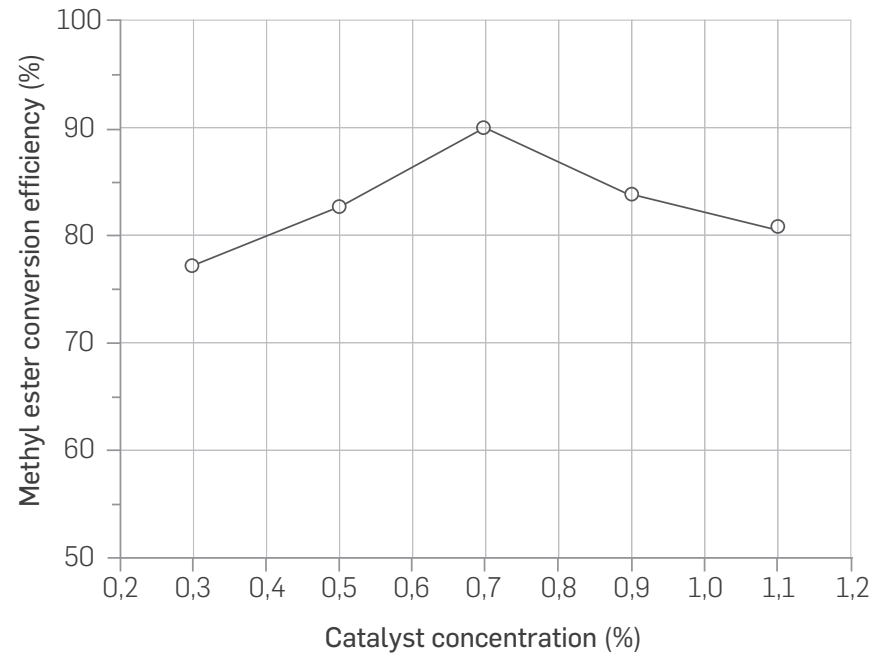

Figure 2. The effect of catalyst concentration on conversion efficiency of methyl ester
Figure 3 shows the effect of methyl alcohol/oil ratio on methyl ester conversion efficiency. In the optimization process, a $0.7 \%$ catalyst concentration, $60^{\circ} \mathrm{C}$ reaction temperature, $600 \mathrm{rpm}$ stirring speed, and 90-minute reaction time were kept constant. Methyl alcohol / oil ratio was changed at intervals of $5 \%$ between $20 \%$ and $40 \%$. The maximum methyl ester conversion efficiency was determined at 25\% methyl alcohol/oil ratio. The yield began to decline when methyl alcohol/oil ratio was higher than 25\%. Methyl ester (biodiesel) and glycerin are the products formed as a result of the reaction of fatty acids with methyl alcohol. As the reaction progresses, the amount of methyl ester and glycerin also increases. Decreases in the yield may have been observed due to the purification problems that emerge during the separation of increasing glycerin from the product [13], [15].

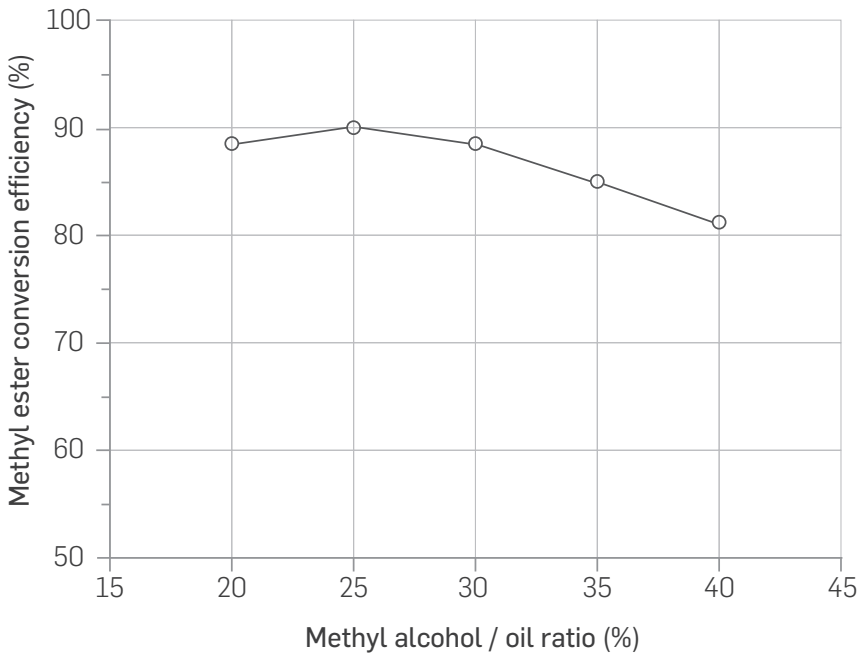

Figure 3. The effect of methyl alcohol/oil ratio on methyl ester conversion efficiency

The effect of reaction temperature on methyl ester conversion efficiency is provided in Figure 4. In the optimization process, a $0.7 \%$ catalyst concentration, $25 \%$ methyl alcohol/oil ratio, 600 rpm, stirring speed, and 90-minute reaction time were kept constant. Reaction was carried out at 40,50,60,70 and $80^{\circ} \mathrm{C}$. The boiling point of methyl alcohol is $63^{\circ} \mathrm{C}$. The maximum conversion efficiency was obtained at $60^{\circ} \mathrm{C}$, which is close to the evaporation temperature of the alcohol. The evaporation tendency of methyl alcohol increased with the increase of the temperature at which the optimum methyl ester conversion efficiency was achieved; the efficiency significantly decreased since the bubbles formed as a result of increasing temperature decreasing the interaction among reactants [13],[15].

Figure 5 shows the effect of reaction time on the methyl ester conversion efficiency. At this stage, a $0.7 \%$ catalyst concentration, $25 \%$ methyl alcohol/oil ratio, $600 \mathrm{rpm}$ stirring speed, and $60^{\circ} \mathrm{C}$ reaction temperature were kept constant. The reaction was carried out for 30,60, 90, 120, and 150 min. The maximum methyl ester conversion efficiency was obtained at 90-minute reaction time. Reaction time had a significant effect on the methyl ester conversion efficiency. This was because longer reaction times led the hydrolysis of esters and caused more fatty acids to produce soap [21].

The maximum methyl ester conversion efficiency was achieved as $90.1 \%$ at a methyl alcohol/oil ratio of $25 \%$, catalyst concentration of $0.7 \%$, stirring speed of $600 \mathrm{rpm}$, reaction temperature of $60^{\circ} \mathrm{C}$, and reaction time of $90 \mathrm{~min}$. Table 3 shows some properties of the methyl ester obtained. The measured fuel properties of methyl ester are within the EN 14214 standard. 


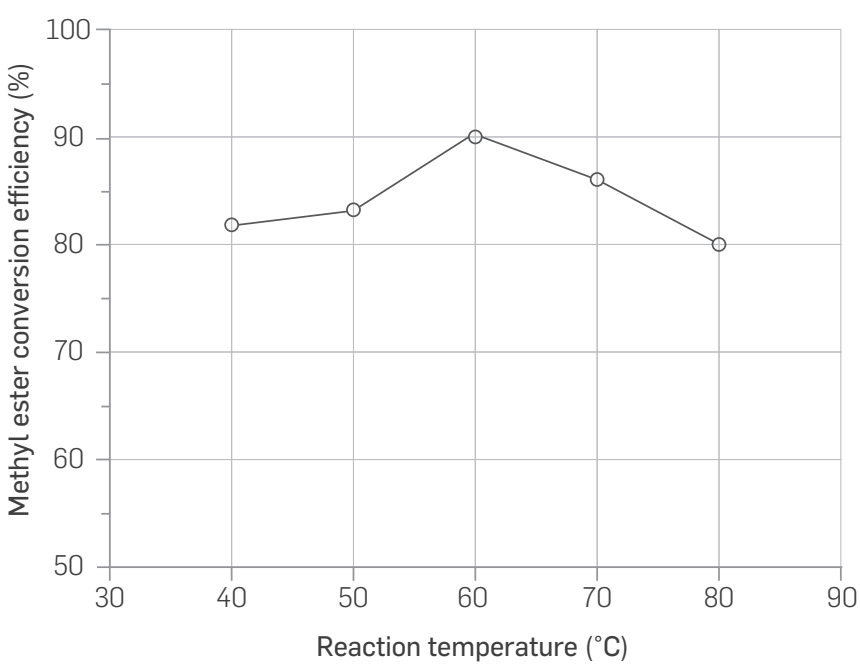

Figure 4. The effect of reaction temperature on methyl ester conversion efficiency

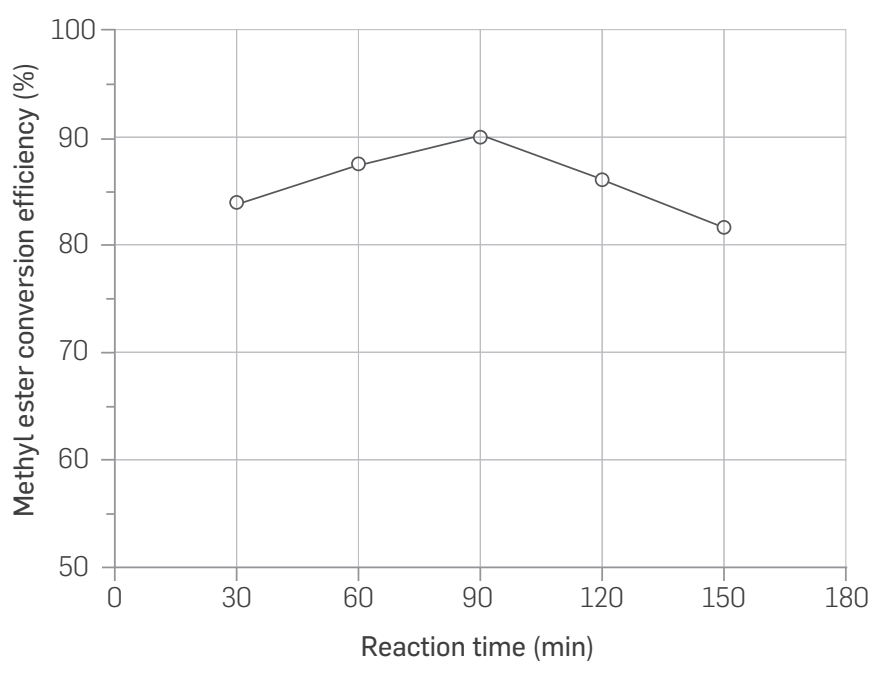

Figure 5. The effect of reaction time on methyl ester conversion efficiency

Table 3. Properties of neutralized waste cooking oil, methyl ester, and diesel fuel

\begin{tabular}{|l|l|c|c|}
\multicolumn{1}{|c|}{ Properties } & $\begin{array}{c}\text { Diesel } \\
\text { Fuel }\end{array}$ & $\begin{array}{c}\text { Neutralized } \\
\text { waste } \\
\text { cooking oils }\end{array}$ & $\begin{array}{c}\text { Methyl } \\
\text { Ester }\end{array}$ \\
\hline Viscosity $(\mathrm{mm} 2 / \mathrm{s})\left(40^{\circ} \mathrm{C}\right)$ & 2.82 & 43.22 & 4.48 \\
\hline Density $(\mathrm{kg} / \mathrm{cm} 3)\left(15^{\circ} \mathrm{C}\right)$ & 0.837 & 0.92 & 0.884 \\
\hline Flash Point $\left({ }^{\circ} \mathrm{C}\right)$ & 60 & $<320$ & 120 \\
\hline Heating Value $(\mathrm{kJ} / \mathrm{kg})$ & 45604 & 37695 & 41826 \\
\hline
\end{tabular}

\section{ENGINE PERFORMANCE AND NOX EMISSIONS}

Figure 6 shows the changes in engine power, engine torque, and specific fuel consumption depending on the engine speed. The maximum engine torque was ascertained as $29.13 \mathrm{Nm}$ at $1600 \mathrm{rpm}$ engine speed with diesel fuel. With the use of methyl ester, engine power was reduced by $3.61 \%$ in comparison to the diesel fuel. The minimum specific fuel consumption was obtained at $2200 \mathrm{rpm}$ engine speed with the diesel fuel. At this engine speed, an increase of $12.8 \%$ was observed in specific fuel consumption with the use of methyl ester. The low calorific value of methyl ester leads to a decrease in engine power with the use of methyl ester. In addition, increases were observed in specific fuel consumption with the use of methyl ester due to the high density and viscosity of methyl ester. The high viscosity and density of methyl ester affects the quality of atomization and leads to a decrease in the reaction zones. Therefore, the specific fuel consumption increases with the use of methyl ester [22],[23].

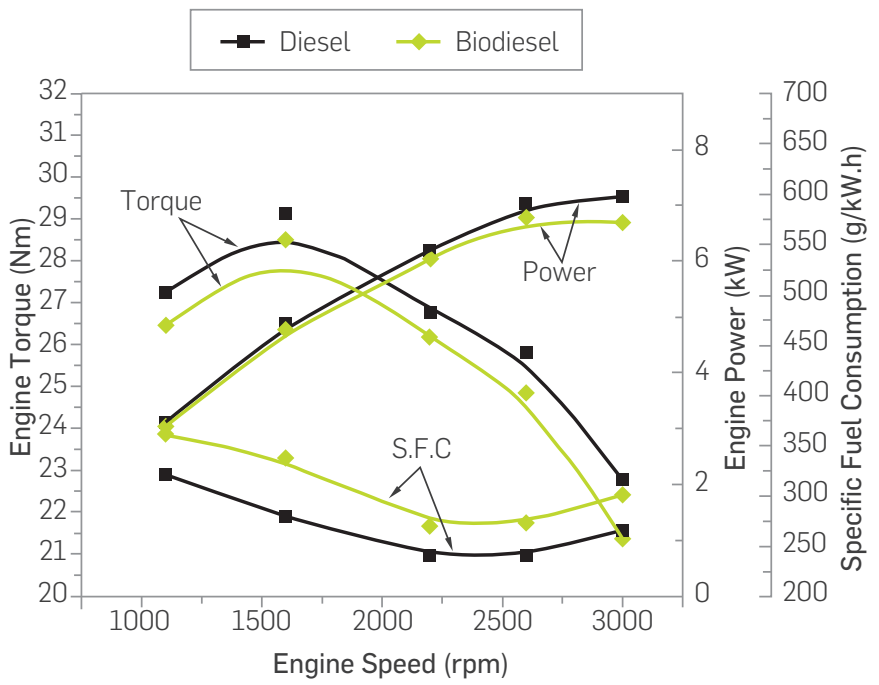

Figure 6. The change in engine power, engine torque, and specific fuel consumption depending on engine speed

Most $\mathrm{NO}_{x}$ emissions originating from internal combustion engines are formed by means of the thermal $\mathrm{NO}_{x}$ mechanism. Thermal $\mathrm{NO}_{x}$ is referred to as $\mathrm{NO}_{x}$ formed by the oxidation of nitrogen in the combustion chamber at high temperatures. The $\mathrm{NO}_{x}$ formation rate is a function of combustion temperature, duration of exposure of nitrogen to temperature, and oxygen content of the reaction zones in the combustion chamber [24].

Figure 7 shows the changes in $\mathrm{NO}_{x}$ emissions depending on engine speed. With the use of methyl ester, $\mathrm{NO}_{x}$ emissions increased by $18.4 \%$ in comparison to the diesel fuel. The number of complete combustion zones is increased due to the fact that specific fuel consumption of methyl ester is higher than that of diesel fuel and its oxygen content provides the oxygen required in fuel-rich zones. Thus, since the number of regions with high ambient temperature increases, a higher amount of nitrogen oxide formation is realized [25]. $\mathrm{NO}_{x}$ increases until the engine speed gives the maximum engine torque and then decreases. Despite the fact that pressure and temperature of flue gas increase with the increase of engine speed, the ignition delay period and residence time of the maximum flue gas temperature decrease. Therefore, $\mathrm{NO}_{x}$ emissions decrease with increasing engine speed [26].

$\mathrm{CO}$ emissions are intermediate combustion products produced as a result of incomplete combustion of the fuel. If the combustion is completed, $\mathrm{CO}$ is converted to $\mathrm{CO}_{2}$. However, $\mathrm{CO}$ may be produced if the combustion is not completed due to lack of air or low exhaust gas temperature [27],[28]. CO emissions, the air-fuel ratio, type 


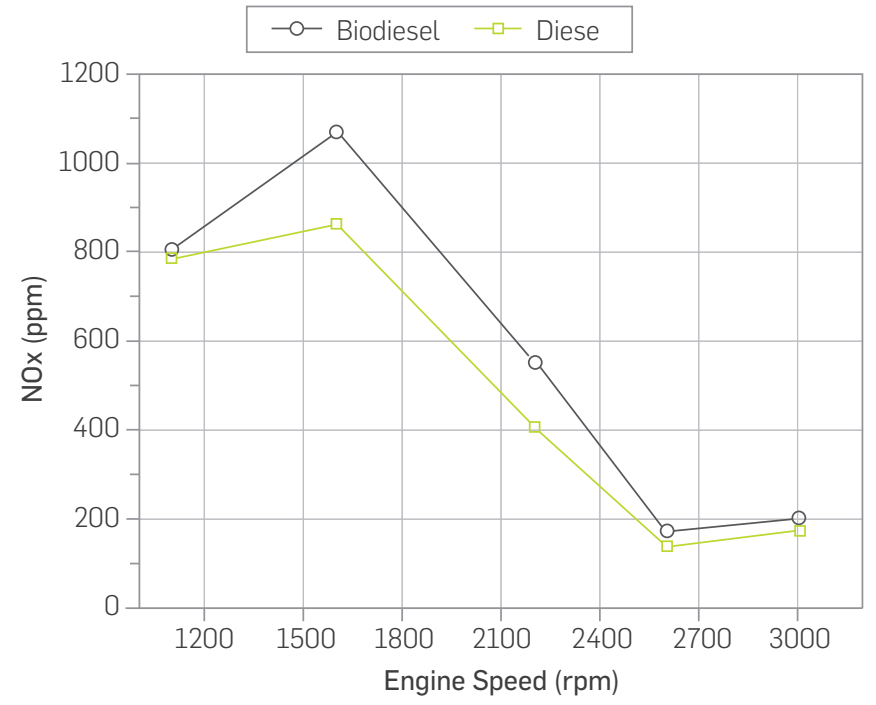

Figure 7. The change in NOx emissions depending on engine speed

of fuel, combustion chamber design, the atomization rate, the start of injection time, injection pressure affect the parameters such as engine load and engine speed. The most important of these parameters is the air-fuel ratio [28],[29]. Figure 8 shows the changes in $\mathrm{CO}$ emission depending on engine speed. The use of methyl ester has led to an average reduction of $12.67 \%$ in $\mathrm{CO}$ emissions in comparison to the diesel fuel. The oxygen content of biodiesels improves the oxidation of hydrocarbons and thus decreases $\mathrm{CO}$ emissions [28],[30].

\section{CONCLUSIONS}

The results obtained from the optimization and engine performance testing processes are as follows;

The maximum conversion efficiency of methyl ester produced from neutralized waste cooking oil was observed

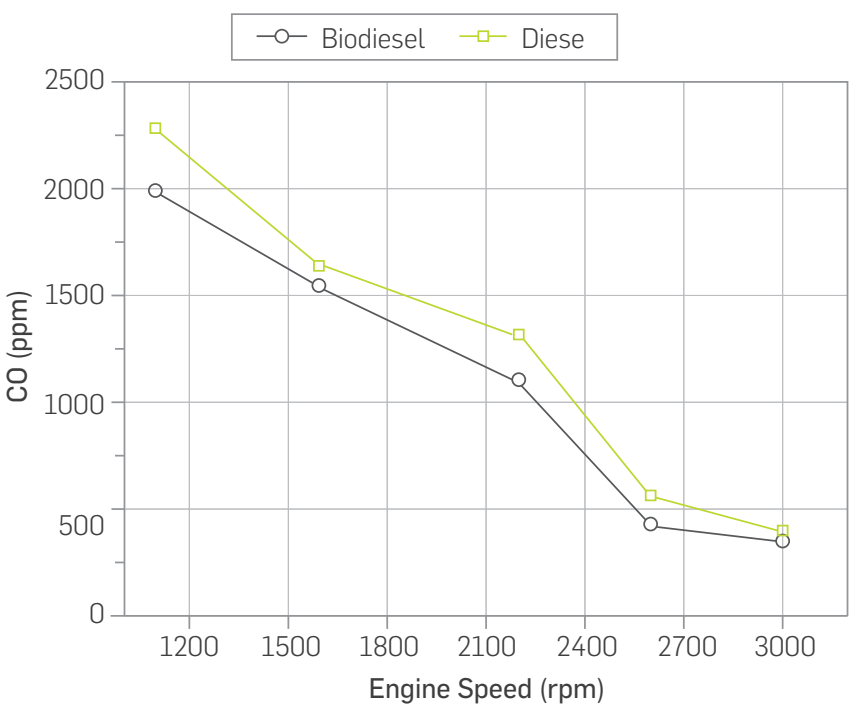

Figure 8. The change in $\mathrm{CO}$ emission depending on engine speed

to be $90.1 \%$ at a $25 \%$ methyl alcohol / oil ratio, $0.7 \%$ catalyst concentration, $600 \mathrm{rpm}$ stirring speed, $60^{\circ} \mathrm{C}$ reaction temperature, and 90 min reaction time.

Due to the low calorific value and high viscosity of methyl ester, an average reduction in engine power of 3.61\% was observed.

Due to the high density and low calorific value of methyl ester, an increase of $12.8 \%$ was observed in specific fuel consumption in comparison to the diesel fuel.

Due to the oxygen content of methyl ester, $12.67 \%$ reduction was observed in $\mathrm{CO}$ emissions.

The number of complete combustion zones increases due to the high specific fuel consumption and oxygen content of methyl ester. Therefore, NOx emissions for methyl ester are higher than diesel fuel.

\section{REFERENCES}

[1] Sayin, C., Ilhan, M., Canakci, M. and Gumus, M. Effect Of Injection Timing On The Exhaust Emissions Of A Diesel Engine Using Diesel-Methanol Blends, Renewable Energy. 2009, 34, 1261-1269.

[2] Yucesu, H. S., Altın, R., Çetinkaya, S. Experimental Investigation of Vegetable Oil Usage As Alternative Fuel In Diesel Engines, Turk J Eng Environ Sci. 2001, $25,39-49$.

[3] Tashtoush, G. M., Al-Widyan, M. I., Al-Jarrah, M. M. Experimental Study on Evaluation and Optimization Of Conversion Of Waste Animal Fat Into Biodiesel, Energy Conversion and Management. 2004, 45, 2697 - 2711.

[4] Demirbas, A., Biodiesel Production From Vegetable Oils Via Catalytic And Non-Catalytic Supercritical Methanol Transesterification Methods, Progress in Energy and Combustion Science. 2005, 31, 466 - 487.
[5] Karabektas, M. The Effects of Turbocharger on The Performance And Exhaust Emissions of A Diesel Engine Fuelled With Biodiesel, Renewable Energy. 2009, 34, $989-993$

[6] Aksoy, F., Bayrakceken, H., Eryilmaz, T. and Aksoy, L. Analyzing The Impact of Using Different Methyl Esters In A Diesel Engine on Engine Performance And Emissions, Energy Education Science and Technology Part A: Energy Science and Research. 2011, 27, 25 - 34.

[7] Aktas, A. and Sekmen, Y. The Effects of Advance Fuel Injection on Engine Performance And Exhaust Emissions of A Diesel Engine Fuelled With Biodiesel, J. Fac. Eng. Arch. Gazi Univ. 2008, 23, 199 - 206.

[8] Issariyakul, T. and Dalai, A. K., Biodiesel from Vegetable Oils, Renewable and Sustainable Energy Reviews, 2014, 31, 446-471.
[9] Jansri, S., Preparation Of Vegetable Oil As Biodiesel Feedstock Via Re-Esterification: A Suitable Catalyst, Energy Procedia, 2015, 79, 143-148.

[10] Can, Ö., Öztürk, E., Solmaz, H., Aksoy, F., Çinar, C. and Yücesu. H. S. Combined Effects of Soybean Biodiesel Fuel Addition and EGR Application on The Combustion and Exhaust Emissions In A Diesel Engine, Applied Thermal Engineering, 2016, 95, 115-124.

[11] Aksoy, L., Process Optimization for Biodiese Production From Nigella Sativa Oil, Energy Education Science and Technology Part A: Energy Science and Research. 2011a, 27, 359 - 366

[12] Eryilmaz, T., Yesilyurt, M. K. Yumak, H. Arslan, M. and Sahin, S., Determination Of The Fuel Properties Of Cottonseed Oil Methyl Ester And Its Blends With Diesel Fuel, International Journal of Automotive Engineering and Technologies. 2014, 3(2) 79-90. 
[13] Meher, L. C., Dharmagadda, V. S. S. and Naik, S. N., Optimization Of Alkali-Catalyzed Transesterification Of Pongamia Pinnata Oil For Production Of Biodiesel, Bioresource Technology. 2006, 97, 1392 - 1397.

[14] Phan, A. N. and Phan, T. M. Biodiesel Production From Waste Cooking Oils, Fuel. 2008, 87, 3490 - 3496.

[15] Aksoy, L Opium Poppy (Papaver somniferum L.) Oil for Preparation of Biodiesel: Optimization of Conditions, Applied Energy. 2011b, 88, 4713 - 4718.

[16] Kafuku, G. and Mbarawa, M. Biodiesel Production from Croton Megalocarpus Oil and Its Process Optimization, Fuel. 2010, 89, 2556 - 2560.

[17] Alptekin, E. and Canakci, M., Optimization of Transesterification For Methyl Ester Production From Chicken Fat, Fuel. 2011, 90, 2630 - 2638.

[18] Sahoo P. K. and Das, L. M., Process optimization for biodiesel production from Jatropha, Karanja and Polanga oils, Fuel. 2009, 88, 1588 - 1594.

[19] Aksoy, F., Alkaline Catalyzed Biodiesel Production from Safflower (Carthamus Tinctorius L.) Oil: Optimization of Parameters and Determination of Fuel Properties, Energy Sources, Part A: Recovery, Utilization, and Environmental Effects, 2016, 38, 835-841.

[20] Eryilmaz, T., Ogut, H., Oguz, H. and Bacak, S. Investigation of The Performance and Emission Values of Non - Standard Fuels at Diesel Engines, Journal of Agricultural Machinery Science. 2010, 6, 45 - 53.

[21] Uzun, B. B., Kilic, M., Ozbay, N., Putun, A. E. and Putun, E. Biodiesel Production From Waste Frying Oils: Optimization of Reaction Parameters and Determination of Fuel Properties, Energy. 2012, 44, 347-351.

[22] Guru, M., Koca, A., Can, O., Cınar, C and Sahin, F., Biodiesel Production From Waste Chicken Fat Based Sources And Evaluation With Mg Based Additive In A Diesel Engine, Renewable Energy. 2010, 35, 637 - 643.

[23] Ozsezen, A. N and Canakci, M. Performance and Combustion In A Direct Injection Diesel Engine Fuelled With Waste Palm And Canola Oil Methyl Esters, J. Fac. Eng. Arch. Gazi Univ. 2009, 24, 275 - 284.

[24] Yao, C., Cheung, C. S., Cheng, C., Wang, Y., Chan, T. L. and Lee, S. C. Effect of Diesel/Methanol Compound Combustion On Diesel Engine Combustion And Emissions, Energy Conversion and Management, 2008 49, 1696 - 1704.

[25] Ozsezen, A. N . and Canakci, M. An Investigation of The Effect Of Methyl Ester Produced From Waste Frying Oil On The Performance And Emissions of An IDI Diesel Engine, J. Fac. Eng. Arch. Gazi Univ. 2008, 23, 395 - 404.

[26] Lin, C. Y. and Li, R. J. Engine Performance And Emission Characteristics of Marine Fish-Oil Biodiesel Produced From The Discarded Parts of Marine Fish, Fuel Processing Technology. 2009, 90, 883 - 888.

[27] Nabi, Md. N., Rahman, Md. N. and Akhter, Md. S. Biodiesel From Cotton Seed Oil and Its Effect on Engine Performance and Exhaust Emissions, Applied Thermal Engineering. 2009, 29, 2265 - 2270.

[28] Bayrakceken, $H_{\text {., }}$ The Effects Of Using Preheated Animal Tallow Biodiesel on Engine Performance and Emissions In A Diesel Engine, Energy Education Science and Technology Part A: Energy Science and Research. $2011,28,133-142$

[29] Sayin, C., Ozsezen, A. N. and Canakci, M. The Influence Of Operating Parameters On The Performance And Emissions of A DI Diesel Engine Using MethanolBlended-Diesel Fuel, Fuel. 2010, 89, 1407-1414.
[30] Canakci, M., Ozsezen, A. N. and Turkcan, A., Combustion Analysis of Preheated Crude Sunflower Oil In An IDI Diesel Engine, Biomass and Bioenergy. 2009, $33,760-767$. 


\title{
APPLICATION OF SPECTRAL INVERSION AND FUZZY LOGIC INTERPOLATION IN POST-STACK RESOLUTION ENHANCEMENT ON A SEISMIC VOLUME OF THE COLOMBIAN LLANOS BASIN
}

\author{
APLICACIÓN DE LA INVERSIÓN ESPECTRAL Y LA INTERPOLACIÓN CON \\ LÓGICA DIFUSA EN EL AUMENTO DE RESOLUCIÓN POST-APILADO EN UN \\ VOLUMEN SÍSMICO DE LA CUENCA LLANOS DE COLOMBIA
}

APLICAÇÃO DA INVERSÃO ESPECTRAL E A INTERPOLAÇÃO COM LÓGICA DIFUSA NO AUMENTO DE RESOLUÇÃO PÓS-EMPILHAMENTO EM UM VOLUME SÍSMICO DA BACIA LLANOS DA COLÔMBIA

Article published on volumen 6, number 4: 08 June 2017

\begin{abstract}
In the published version, the article accepted date was incorrectly wrote as 'Jul. 05, 2017'
The correct date should read as follow:
\end{abstract}

(Received: Nov 28, 2016; Accepted: May. 29, 2017)

This error has now been corrected in the PDF and HTML paper versions 